Proceedings

\title{
Experimental Study on Hollow Blocks with Wastes ${ }^{\dagger}$
}

\author{
Ligia Hanuseac *, Marinela Barbuta *, Liliana Bejan, Raluca Rosu \\ and Alexandru Timu
}

Faculty of Civil Engineering and Building Services, Department of Concrete, Materials, Technology and Management, "Gheorghe Asachi” Technical University of Iasi, 700050 Iasi, Romania;

lilbejan@yahoo.com (L.B.); ana-raluca.rosu@academic.tuiasi.ro (R.R.); alexandru.timu@gmail.com (A.T.)

* Correspondence: ligyahanuseac@gmail.com (L.H.); barbuta31bmc@yahoo.com (M.B.)

+ Presented at the 14th International Conference on Interdisciplinarity in Engineering-INTER-ENG 2020,

Târgu Mureș, Romania, 8-9 October 2020.

Published: 7 February 2021

\begin{abstract}
The article presents an experimental study on concrete blocks prepared by using waste types such as fly ash as a cement substitution, waste of plastic bottles and wood waste as replacements for sand and polyester fibers waste as a dispersed reinforcement. The mechanical characteristics of concrete with fly ash and polyester fibers were determined. The influence of the type and dosage of waste on the mechanical strength is discussed. The concretes with fly ash and different dosages of waste were used for manufacturing hollow blocks that were tested in compression, and the behavior under load was analyzed. Failure in compression of hollow blocks was gradual and ductile.
\end{abstract}

Keywords: eco concrete; fly ash; waste

\section{Introduction}

Concrete is one of the most used materials in construction and engineers have worked to ensure concrete responds to new requirements related to environment protection [1,2]. Production of cement, an important component of concrete, is a cause of $\mathrm{CO}_{2}$ emission (7\%), and the huge quantities of natural aggregates used in the concrete composition result in important changes in the natural environment. Non-conventional concretes, with different types of materials in the mix, have emerged just for partially eliminating the above ecological problems. The cement is replaced partially or totally by different materials, such as fly ash, silica fume, slag, rice husk and banana leaves ash [3-8]. Aggregates have been replaced by steel slag, chopped plastic bottles, polystyrene granules, recycled aggregates, chopped sunflower, etc. [9-13]. Fibers of diverse types have also been added in the concrete mix: steel, polyester, hemp, etc. [14-18]. The main objective of the article was to analyze the behavior of hollow blocks manufactured with concrete prepared with a cement substitution with fly ash and waste types such as chopped plastic bottles and wood waste as replacements for sort 0-4 mm and polyester fibers as a dispersed reinforcement. The hollow blocks manufactured with nonconventional concretes will be used to make a non-load-bearing masonry wall. In the next stage, this masonry wall will be built and tested.

\section{Experimental Program}

\subsection{Materials}

In the research, a control mix of concrete $\left(\mathrm{C}_{0}\right)$ was used for preparing hollow blocks which had the following components: cement type CEM I $42.5 \mathrm{R}$ [19] in a dosage of $360 \mathrm{~kg} / \mathrm{m}^{3}$; and river aggregates in three sorts, namely $0-4 \mathrm{~mm}, 4-8 \mathrm{~mm}$ and $8-16 \mathrm{~mm}$, which were in the following 
dosages: $803 \mathrm{~kg} / \mathrm{m}^{3}$ of sand, $384 \mathrm{~kg} / \mathrm{m}^{3}$ of sort $4-8 \mathrm{~mm}$ and $559 \mathrm{~kg} / \mathrm{m}^{3}$ of sort $8-16 \mathrm{~mm}$. We used water in a dosage of $1721 / \mathrm{m}^{3}$, and $10 \%$ of the cement dosage was replaced with fly ash, from CET Holboca Iasi. Fly ash was used before in other experimental tests and presented by the authors in $[15,20]$. Waste types PET bottles and wood waste were chopped into sorts of $0-4 \mathrm{~mm}$ and used as replacements for $20 \%$ by volume of the dosage of aggregate sort $0-4 \mathrm{~mm}$ in the case of PET and $40 \%$ by volume of the dosage of the same aggregate sort in the case of wood. The chopped PET and wood waste had sizes between 0 and $4 \mathrm{~mm}$. Waste from polyester fibers was used, which was cut into $30 \mathrm{~mm}-$ long filaments and dispersed as a replacement reinforcement in the concrete, in a dosage of $0.25 \%$ of the concrete weight. In the mixture, we used a superplasticizer (Master Glenium SKY 617 from BASF) in a dosage of $1 \%$ of the cement volume.

\subsection{Samples}

The control mix of concrete (noted $\mathrm{C}_{0}$ ) and the mixes with fly ash and chopped PET (noted $\mathrm{C}_{1}$ ), fly ash and wood waste (noted $\mathrm{C}_{2}$ ) and fly ash and polyester fibers (noted $\mathrm{C}_{3}$ ) were prepared by mixing all the components. The wood waste was moistened before being added to the mix. The samples were poured: cubes of $150 \mathrm{~mm}$ in size for determining the compressive strength $\mathrm{fc}$, and prisms of $100 \times 100 \times$ $500 \mathrm{~mm}$ in dimension for determining the flexural strength $\mathrm{fti}_{\mathrm{i}}$ and split tensile strength $\mathrm{ftd}_{\mathrm{td}}$ [21-23]. The hollow blocks, one of which is shown in Figure 1, labeled HBF1-HBF3 were manufactured only for the concretes with waste (concretes $\mathrm{C}_{1}-\mathrm{C}_{3}$ ). After $24 \mathrm{~h}$, the specimens were removed from the formwork and kept in the laboratory at a temperature of $20^{\circ} \mathrm{C}$ until testing.

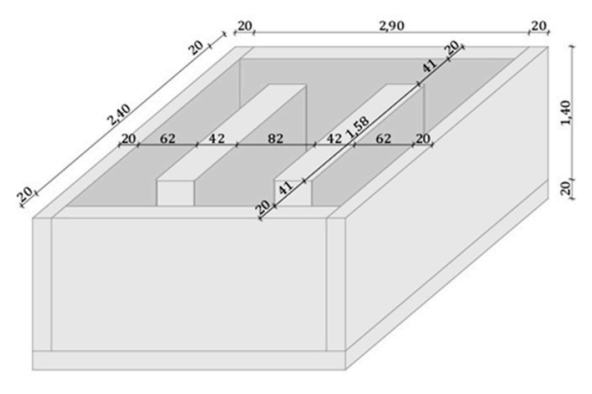

(a) Digital drawing of the hollow block

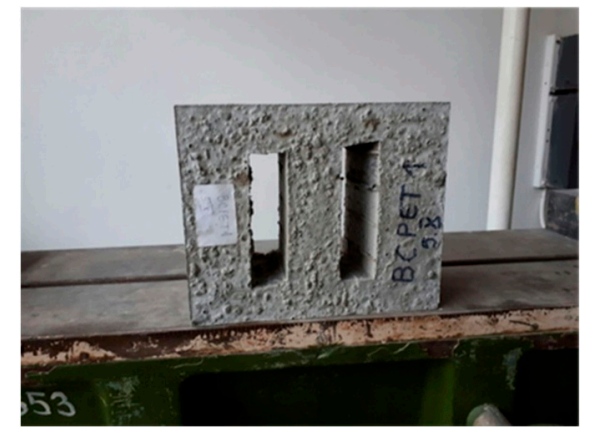

(b) Hollow block

Figure 1. The experimental hollow blocks.

\section{Testing Result and Discussion}

\subsection{Mechanical Strength of Concrete Mixes}

The control mix and the concretes with waste were tested at 28 days for mechanical strength. The values are given in Table 1.

Table 1. Mechanical characteristics of experimental concretes.

\begin{tabular}{cccc}
\hline Concrete Sample & $\begin{array}{c}\mathbf{f}_{\mathbf{c}} \\
\mathbf{N} / \mathbf{m m}^{2}\end{array}$ & $\begin{array}{c}\mathbf{f}_{\mathbf{t i}} \\
\mathbf{N} / \mathbf{m m}^{2}\end{array}$ & $\begin{array}{c}\mathbf{f}_{\text {td }} \\
\mathbf{N} / \mathbf{m m}^{2}\end{array}$ \\
\hline Control C & 33.45 & 1.82 & 1.72 \\
$\mathrm{C}_{1}$ & 25.27 & 1.74 & 1.82 \\
$\mathrm{C}_{2}$ & 13.63 & 1.30 & 1.24 \\
$\mathrm{C}_{3}$ & 29.80 & 2.01 & 1.94 \\
\hline
\end{tabular}

\subsubsection{Compressive Strength}


The value of $f_{c}$ for concretes with waste was influenced by the type of waste. All values of $f_{c}$ were lower than that of the control mix. The replacement of sort 0-4 $\mathrm{mm}$ with chopped plastic in a dosage of $20 \%$ had reduced $\mathrm{fc}_{\mathrm{c}}$, with $24.5 \%$, in comparison with the control mix. In the case of the replacement of sand with $40 \%$ sawdust, $\mathrm{f}_{\mathrm{c}}$ was reduced, with $52 \%$, and mix $\mathrm{C}_{3}$ (only with fly ash and polyester fibers) presented a decrease in $\mathrm{f}_{\mathrm{c}}$ of only $11 \%$ in comparison with the control mix. For $\mathrm{f}_{\mathrm{c}}$, the highest value was obtained for concrete $\mathrm{C}_{3}$.

\subsubsection{Flexural Strength}

The value of flexural strength was influenced by the type and dosage of waste. When the aggregates of sort $0-4 \mathrm{~mm}$ were replaced, a decrease in flexural strength was obtained. The addition of polyester fibers increased the flexural strength by $10 \%$ in comparison with the control mix. For $\mathrm{fti}_{\mathrm{t}}$ the highest value was obtained for concrete $C_{3}$.

\subsubsection{Split Tensile Strength}

The value of split tensile strength was influenced by the type and dosage of waste. The waste type chopped PET as a replacement for sort $0-4 \mathrm{~mm}$ in a dosage of $20 \%$ resulted in an increase in the strength. The waste type wood waste as a replacement for sort $0-4 \mathrm{~mm}$ in a dosage of $40 \%$ resulted in a decrease in the strength. The dispersed polyester fibers increased the split tensile strength in comparison with the control mix by $12.8 \%$.

The mechanical strengths of concretes with different waste types as replacements for aggregates were lower than those of the control mix. In the case of concrete with fly ash and polyester fibers, the compressive strength was lower than that of the control mix, but the flexural strength and split tensile strength were highest.

\subsection{Hollow Blocks Experimental Test}

The blocks of concrete were subjected to axial compression. The compression force was applied along with the height of the block. The maximum value of the compression load was divided by the gross contact area of the block, including holes, noted $\mathrm{f}_{\mathrm{cb} 1}$, and by the net area, noted $\mathrm{f}_{\mathrm{cb} 2}$.

The indirect tension stress, according to [24], was computed with the following relation (1):

$$
\mathrm{f}_{\mathrm{tb}}=2 \mathrm{P} / \pi \mathrm{Lh},
$$

where $\mathrm{P}$ is the value of the maximum compression load, $\mathrm{h}$ is the height of the block $(140 \mathrm{~mm})$ and $\mathrm{L}$ is the split length $(82 \mathrm{~mm}$ ) if the holes are neglected, or $240 \mathrm{~mm}$ if the total length is considered.

The results of the experimental tests are given in Table 2.

Table 2. Experimental results of the compression test on the hollow blocks.

\begin{tabular}{cccccccc}
\hline No. & Block & $\begin{array}{c}\text { Sizes of Blocks } \\
\mathbf{m m}\end{array}$ & $\begin{array}{c}\text { Maximum } \\
\text { Compression } \\
\text { Force kN }\end{array}$ & $\begin{array}{c}\mathbf{f}_{\mathrm{cb} 1} \\
\mathbf{N} / \mathbf{m m}^{2}\end{array}$ & $\begin{array}{c}\mathbf{f}_{\mathrm{cb} 2} \\
\mathbf{N} / \mathbf{m m}^{2}\end{array}$ & $\begin{array}{c}\mathbf{f}_{\mathrm{tb} 1} \\
\mathbf{N} / \mathbf{m m}^{2}\end{array}$ & $\begin{array}{c}\mathbf{f}_{\text {tb2 }} \\
\mathbf{N} / \mathbf{m m}^{2}\end{array}$ \\
\hline $\mathrm{C}_{1}$ & $\mathrm{HBF1}$ & $240 \times 290 \times 140$ & 815.00 & 11.71 & 14.29 & 4.53 & 1.54 \\
$\mathrm{C}_{2}$ & $\mathrm{HBF} 2$ & $240 \times 290 \times 140$ & 390.42 & 5.71 & 6.85 & 2.17 & 0.74 \\
$\mathrm{C}_{3}$ & HBF3 & $240 \times 290 \times 140$ & 925.21 & 13.3 & 16.21 & 5.13 & 1.75 \\
\hline
\end{tabular}

The compressive strengths $\mathrm{f}_{\mathrm{cb}}$ of the blocks had different values, depending on the type of concrete. According to [24], the minimum compressive strength must be $7 \mathrm{~N} / \mathrm{mm}^{2}$ and the blocks with fly ash and PET waste (HBF1) and those with fly ash and polyester fibers (HBF3) satisfy this condition for their use in masonry also in seismic areas, as a self-weight masonry for realizing partitioning walls [24]. The block HBF2 can be used for self-weight masonry.

The split tensile strength $\mathrm{ftb}_{\mathrm{tb}}$ of blocks also had good values which are in concordance with values given by other authors [11]. 
The mechanical characteristics of hollow blocks recommend them to be used in construction for realizing masonry walls. 


\subsection{Failure Mode}

During the tests in compression, the blocks failed gradually, and vertical cracks developed throughout the entire depth, especially near holes. The blocks had a ductile failure until the complete damage, as shown in Figure 2.

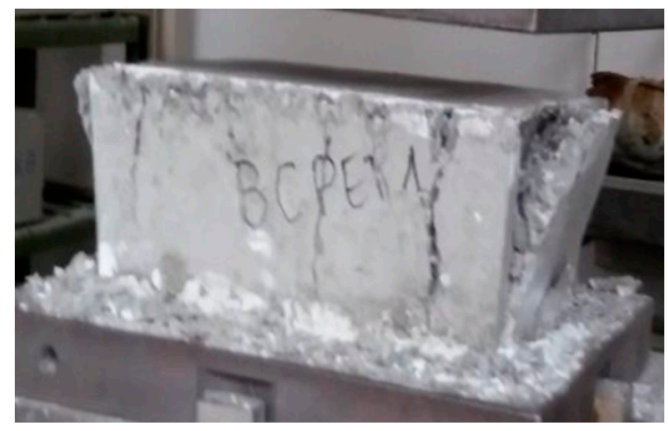

(a) HBF1

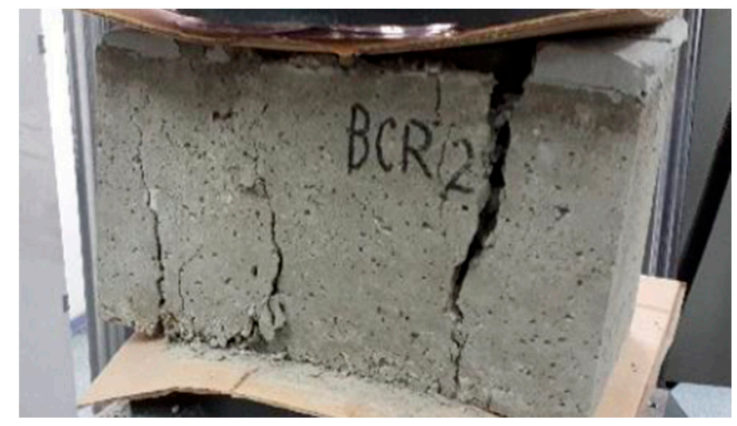

(b) HBF2

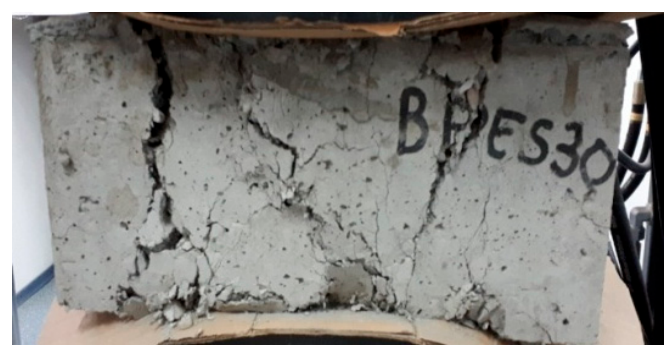

(c) HBF3

Figure 2. Failure of hollow blocks HBF1, HBF2 and HBF3.

\section{Patents}

For manufacturing the blocks, the following types of waste were used for preparing concrete: fly ash that replaced $10 \%$ of cement in all mixes with waste, chopped plastic bottles (PET) that replaced aggregate sort $0-4 \mathrm{~mm}$ in a dosage of $20 \%$ by weight, waste of wood that replaced aggregate sort $0-4 \mathrm{~mm}$ in a dosage of $40 \%$ by weight and waste of polyester fibers that was added in the mix with fly ash.

The compressive strength, tensile strength and split tensile of the concretes with waste were determined. The type and dosage of waste influenced the mechanical properties. For all types of concrete, the value of compressive strength was lower than that of the control mix without waste. In the case of concrete with polyester fibers, the flexural strength and split tensile strength were higher than those of all others mixes. For concretes with saw dust, the lowest values of all mechanical strengths were obtained.

When tested in compression, the hollow blocks presented values of compressive strength and tensile strength comparable with other types of blocks, which means we can recommend their use for realizing walls.

Author Contributions: Conceptualization, L.H.G. and M.B.; methodology, M.B.; formal analysis and investigations, L.H.G., L.B., R.R., A.T., resources L.H.G., M.B. and A.T.; data curation, L.H.G. and M.B.; writingoriginal preparation, L.H.G.; writing-review and ending, L.H.G., M.B., L.B., R.R. and A.T.; supervision, M.B.; project administration, M.B. All authors have read and agreed to the published version of the manuscript.

Funding: This research recived no external funding.

Conflicts of Interest: The authors declare no conflict of interest. 


\section{References}

1. Khan, R.; Jabbar, A.; Ahmad, I.; Khan, W.; Khan, A.N.; Mirza, J. Reduction in environmental problems using rice-husk ash in concrete. Constr. Build. Mater. 2012, 30, 360.

2. Eun, O.J.; Monteiro, P.J.M.; Sun, J.S.; Sejin, C.; Clark, S. The evolution of strength and crystalline phasis of alkali-activated ground blast furnace slag and fly ash-based geopolymers. Cem. Concr. Res. 2010 40, 189.

3. Gencel, O.; Koksal, F.; Ozel, C.; Brostow, W. Combined effect of fly ash and waste ferrochromium on properties of concrete. Constr. Build. Mater. 2012, 29, 633.

4. Harja, M.; Barbuta, M.; Gavrilescu, M. Study of morphology for geopolymer materials obtained from fly ash. Environ. Eng. Manag. J. 2009, 8, 1021.

5. Zoum, K.S.; Moon, J.; Cho, JY.; Kim, J.J. Experimental study on strength and durability of lightweight aggregate concrete containing silica fume. Constr. Build. Mater. 2016, 114, 517.

6. Garg, C.; Khadwal, A. Behavior of ground granulated blast furnace slag and limestone powder as partial cement replacement. Int. J. Eng. Adv. Technol. 2014, 393.

7. Van, V.T.A.; Rößler, C.; Bui, D.D.; Ludwig, H.M. Mesoporous structure and pozzolanic reactivity of rice husk ash in cementitious system. Constr. Build. Mater. 2013, 43, 208.

8. Kanning, R.; Portella, K.; Braganca, M.; Bonato, M.J. dos Santos Banana leaves ashes as pozzolan for concrete and mortar of Portland cement. Constr. Build. Mater. 2014, 54, 460.

9. Yu, X.; Tao, Z.; Song, T.Y.; Pan, Z. Performance of concrete made with steel slag and waste glass. 2016 Constr. Build. Mater. 2016, 114, 737.

10. Islam, M.J.; Meherier, M.S.; Rakinul, A.K.M. Effects of waste PET as coarse aggregate on the fresh and harden properties of concrete. Constr. Build. Mater. 2016, 125, 946.

11. Xu, Y.; Jiang, L.; Xu, J.; Li, Y. Mechanical properties of expanded polystyrene lightweight aggregate concrete and brick. Constr. Build. Mater. 2012, 27, 32.

12. Gonzalez-Corominas, A.; Etxeberria, M. Effects of using recycled concrete aggregates on the shrinkage of high performance concrete. Constr. Build. Mater. 2016, 115, 32.

13. Helepciuc Gradinaru, C.M.; Barbuta, M.; Serbanoiu, A.A. Characterization of a lightweight concrete with sunflower aggregates. Proc. Manufac. 2018, 22, 154.

14. Serbanoiu, A.A.; Barbuta, M.; Burlacu, A.; Gradinaru, C.M. Fly ash cement concrete with fiberscomparative study. Environ. Eng. Manag. J. 2017, 16, 1123.

15. Barbuta, M.; Marin, E.; Cimpeanu, S.M.; Paraschiv, G.; Lepadatu, D.; Bucur, R.D. Statistical analysis of the tensile strength of coal fly ash concrete with fibers using central composite design. Adv. Mat. Sc. Eng. 2015, $15,24$.

16. Awada, E.; Mabsoud, M.; Hmad, B.; M. Farran, H. Khatib, Studies on fiber reinforced concrete using industrial hemp. Constr. Build. Mater. 2012, 35, 710.

17. Caroll, J.C.; Helminger, N. Fresh and hardened properties of fiber-reinforced rubber concrete. J. Mater Civ. Eng. 2016, 28, 15.

18. Urkhanova, L.; Lkhasaranov, S.; Buiantuev, S. Fiber-reinforced concrete with mineral fibers and nanosilica. Proced. Eng. 2017, 195, 147.

19. SR EN 197-1:2011 Cement, Part 1: Composition, Specifications and Conformity Criteria for Common Cements; Romanian Standard Association: Bucharest, Romania.

20. Timu, A. Effects of Using Additions on the Properties of Concrete; Universitatea Tehnica Gheorghe Asachi: Iasi, Romania, 2018.

21. SR EN 12390-3: 2011.Testing Hardened Concrete. Part 3: Compressive Strength of Test Specimens; Romanian Standard Association: Bucharest, Romania.

22. SR EN 12390-4:2010. Testing Hardened Concrete. Part 6: Flexural Strength of Test Specimens; Romanian Standard Association: Bucharest, Romania.

23. SR EN 12390-4:2010. Testing Hardened Concrete. Part 7: Split Tensile Strength of Test Specimens; Romanian Standard Association: Bucharest, Romania.

24. SR EN 771-4:2004 Specifications for Masonry. Part 4: Blocks for Masonry of Cellular Aerated Concrete; Romanian Standard Association: Bucharest, Romania. 
Publisher's Note: MDPI stays neutral with regard to jurisdictional claims in published maps and institutional affiliations.

(c) 2021 by the authors. Submitted for possible open access publication under the terms and conditions of the Creative Commons Attribution (CC BY) license (http://creativecommons.org/licenses/by/4.0/). 